\title{
PerCursos
}

\section{“Da praça pública ao palácio": a atuação da imprensa cearense na cultura da memória do cangaço (1982-1995)}

\begin{abstract}
Resumo
O artigo realiza uma análise da cultura da memória do cangaço na cena pública cearense do tempo presente com atenção particular à atuação da imprensa no processo em relevo. Apresenta aspectos da sua ressignificação como um tipo de tema sensível do Nordeste Brasileiro, durante o terço final do século XX, notando o lugar do estado cearense em movimento nordestino responsável pela revisitação, fortalecimento e patrimonialização que a envolve em vários usos de desejo de tradição gestados entre acordos e conflitos; observa a atuação de uma governança específica, formada pelo jornal O Povo em articulação com a Secretaria de Cultura do Ceará, no processo de empreendedorismo dessa memória; atenta para a operação midiográfica mobilizada na imprensa cearense em diferentes momentos, analisando como se constroem memórias através de narrativas de revisão, reflexão e reavaliação desse passado. Em seu curso, destaca ações centrais no período, a fim de problematizar algumas representações da memória em jogo.
\end{abstract}

\author{
Vagner Silva Ramos Filho \\ Doutorando em História na \\ Universidade Estadual de \\ Campinas - UNICAMP. \\ Brasil \\ vagner_ramosf@hotmail.com
}

Palavras-chave: Cangaço. Lampião. Memória. Ceará. Imprensa. Patrimônio.

\section{Para citar este artigo:}

RAMOS FILHO, Vagner Silva. "Da praça pública ao palácio": a atuação da imprensa cearense na cultura da memória do cangaço (1982-1995). Revista PerCursos, Florianópolis, v. 20, n.42, p. 68 - 104, jan./abr. 2019.

DOI: $10.5965 / 1984724620422019068$

http://dx.doi.org/10.5965/1984724620422019068 


\title{
"From the public square to the palace": cultural bases of the memory of cangaço in the state of Ceará - Brazil (1982-1995)
}

\begin{abstract}
The article analyzes the culture of the memory of cangaço as seen in the public scene of the state of Ceará, also presenting resignification aspects of the memory of cangaço as a type of 'an ever present Brazilian northeastern past' during the final third of the twentieth century, seeing how the state of Ceará engages itself in the northeast movement which accounts for its revisiting, strengthening and preservation; it observes the action of a specific governance from the state of Ceará, made up by Jornal do Povo in conjunction with the Secretariat of Culture of the State in the entrepreneurship process of this memory; it also focuses on the mediagraphical operation in the printing press of the state of Ceará over different moments, analyzing how memories are constructed through narrative reviews, reflection, and reevaluation of this past. Lastly, it highlights central actions of this period, aiming at problematizing some representations of these key issues merit.
\end{abstract}

Keywords: Cangaço. Lampião. Memory. Ceará (Brazil). Press. Heritage. 


\section{Introdução}

Em 19 de julho de 1982, dois meses após a exibição nacional da minissérie “Lampião e Maria Bonita”, que ampliou o interesse pela memória do cangaço no país, o jornal cearense O Povo, periódico de grande circulação, inicia uma série de reportagens acerca de polêmicas do fenômeno. A série, assinada pelo jornalista Fenelon de Almeida, é baseada em depoimentos de testemunhas do cangaço, colhidos durante suas viagens pelo Nordeste. Na primeira reportagem, o jornalista afirma que "hoje virou moda falar em cangaço", o que sugere desdobrar-se, muitas vezes, em pura "mentira”. Daí sua opção em ter saído "à procura de provas junto a diversas pessoas idôneas", insinuando que o periódico seria capaz de levar mais "verdade" ao público".

A atuação do O Povo, com suas muitas notícias, cadernos e empreendimentos relacionados ao tema, é uma porta de entrada pertinente para que se entenda historicamente a construção de algumas bases da cultura da memória do cangaço na cena pública cearense, principalmente a partir da imprensa, por meio da análise dos usos variados que a contornam envolvidos mais por um tipo de desejo de tradição do que um dever de memória. De partida, não custa salientar, conforme coloca Elizabeth Jelin (2002, p. 49), que "a gestação de uma questão pública", como o que ocorreu com o caso aqui investigado, é um "processo que se desenvolve ao longo do tempo e que requer energia".

Partindo disso, levantamos as seguintes questões, com intuito de nortear a estrutura do trabalho: como ocorreu a passagem dos cangaceiros em alguns estados do Nordeste brasileiro, particularmente no Ceará? Como a memória do cangaço foi preservada, transmitida e ressignificada na cena pública desse estado, no tempo presente? Em que medida, a observação do contexto das comemorações do cinquentenário de morte de Lampião, em 1988, tão basilar em alguns estados da região, quando se trata da revisitação do assunto após a redemocratização, contribui com o entendimento desse processo gestado entre acordos e conflitos? Como a análise dos

\footnotetext{
${ }^{1}$ A análise da reportagem será desenvolvida, especificamente, na terceira parte do artigo - "Operações midiográficas da memória: (in)formações públicas do cangaço".
} 
“Da praça pública ao palácio": a atuação da imprensa cearense na cultura da memória do cangaço (19821995)

jornais cearenses permite entender o debate, compreendendo tanto as ações de instituições, grupos e indivíduos, quanto as representações que mobilizam?²

\section{Cangaço, cultura da memória e Nordeste: notas sobre um tema sensível}

O cangaço foi um fenômeno de banditismo vivenciado no sertão do Nordeste brasileiro entre a segunda metade do século XIX e a primeira metade do século $X X$. Entende-se banditismo como prática reconhecida oficialmente como um tipo de criminalidade, mesmo que o cangaço não se reduza a simples manifestação marginal, pois se imbuiu de diversidade de elementos que forneceram-lhe construção sociocultural bastante singular (HOBSBAWM, 1975; WIESEBRON, 1997; MELLO, 2004; PERICÁS, 2010;)3. O período áureo do fenômeno teria acontecido entre os anos de 1916 e 1938, em um intervalo que compreende a entrada, a liderança e a morte, no meio bandoleiro, de Virgulino Ferreira da Silva, mais conhecido como Lampião, o "Rei do Cangaço".

Nesses anos, o ciclo lampiônico, como também é chamado o período, foi marcado por elementos muito particulares, como a indumentária, a linguagem, as táticas de guerrilha e as relações com as mulheres, os sertanejos, os fazendeiros e a polícia (PERICÁS, 2011)4. Depois da morte de Lampião, sua companheira Maria Bonita e outros importantes bandoleiros, em 1938, encomendada pelo Governo Federal por considerá-los estorvos ao processo de centralização político-administrativa que se tentava impor com o chamado Estado Novo (1937-1945), suas cabeças decepadas e seus despojos foram

\footnotetext{
2 Ressalta-se que esse trabalho resulta de um capítulo modificado de nossa dissertação de mestrado (RAMOS FILHO, 2016) escrita no âmbito do Grupo de Estudo e Pesquisa em Patrimônio e Memória (UFC/CNPq), com atualização advinda igualmente da inserção no Grupo de Pesquisa Cultura Visual, Imagem e História (UNICAMP/CNPq) e no Grupo de Pesquisa História Popular do Nordeste (UFS/CNPq). Parte do texto agora ampliado foi publicado nos anais completos do III Seminário Nacional de História e Contemporaneidades, na Universidade Regional do Cariri (URCA), em 2018, sob o título: "Governanças de um "bom negócio: usos do cangaço na reestruturação da política cultural cearense".

${ }^{3}$ A discussão sobre definições de banditismo e cangaço tem larga extensão. Para os/as interessados/as em aprofundar $\mathrm{o}$ assunto, recomenda-se, incialmente, a leitura das obras indicadas.

${ }^{4}$ Alguns outros fatores que permitem entender o porquê deste cangaceiro ter conquistado o epíteto de "Rei do Cangaço" são: a grande estruturação e atuação ampla e longeva de seu bando; a integração diversificada do bando, que contava com a presença de mulheres, crianças e até animais de estimação; a ideia de que Lampião nunca abandonou o cangaço, não se rendeu, nem foi preso, diferentemente de outros líderes cangaceiros; e o maior alcance da mídia (rádios, revistas e jornais), que divulgava várias fotos e histórias de sua trajetória (PERICÁS, 2011).
} 
tomados como troféus da força da repressão estatal contra o banditismo e exibidos pelas cidades nordestinas para inibir qualquer prática semelhante. Não obstante, as cabeças foram conservadas no Museu do Instituto Médico Legal Nina Rodrigues, do estado da Bahia, sob justificativa de interesse científico e etnológico, e a liberação só ocorreu em 1969, ou seja, mais de três décadas após suas decapitações5.

Nas cidades do interior nordestino, que se transformaram em pontos de apoio e/ou de obstáculo para os bandoleiros, costumam-se destacar alguns marcos tradicionais da trajetória de Virgulino. No ano de 1897, Lampião nasceu, em Serra Talhada-PE, onde viu sua família, os Ferreiras, entrar em conflito com outra rival, os Saturninos; ao longo da vida, teve inúmeros combates, sobretudo com os perseguidores de cangaceiros conhecidos como Nazarenos, de Floresta-PE; em 1924, travou combate com outro perseguidor, Clementino Quelé, em Triunfo-PE; em 1926, teria recebido, supostamente de Padre Cícero, convite para ser capitão de "Batalhão Patriótico" na luta contra a Coluna Prestes, em Juazeiro do Norte-CE; em 1927, perdeu o primeiro grande combate, que resultou na morte de um de seus cangaceiros, o Jararaca, em Mossoró-RN; em 1929, conheceu sua companheira Maria Bonita, em Paulo Afonso-BA; em 1938, enfrentou a volante ${ }^{6}$ liderada pelo tenente João Bezerra, que partiu de Piranhas-AL rumo à Gruta de Angico, um esconderijo até então tido como seguro, em Poço Redondo-SE, local onde morreu.

Na estadia em terras do Cariri cearense, Lampião concedeu uma das únicas entrevistas de que se tem notícia, a qual foi publicada no Jornal O Ceará, periódico da capital do estado, em 17 de março de 19267. "A concessão fictícia da patente de capitão ao cangaceiro marcou sua trajetória na vida pública" e, por mais que o fascínio em torno do cangaço tenha sido criado por meios como a literatura de cordel, "Lampião teve a particularidade de saber jogar com a imprensa", bem como "com todos os registros do visual para magnificar a vida que levava com seu grupo e transmitir a imagem de um

\footnotetext{
5 Estácio de Lima, diretor do Instituto, alegava que as cabeças mumificadas eram “[...] documentos inestimáveis de uma época da criminalidade brasileira" (LIMA, 1965).

${ }^{6} \mathrm{~A}$ volante é um tipo de polícia formada especialmente para perseguir cangaceiros.

7 No Cariri cearense ficam os municípios de Crato, Juazeiro do Norte e Barbalha. A entrevista foi realizada pelo médico Otacílio Macêdo, na cidade do Crato-CE.
} 
bandido rico e poderoso, que amava essa vida" (GRUSPAN, 2006, p. 95 e 115).

A despeito desse itinerário, que oferece uma mínima orientação no assunto, o interessante é sinalizar que o fim do cangaço não significou seu esquecimento nessas cidades e que esses marcos cronológicos são basilares na construção de memória que diversos grupos fazem em torno do fenômeno (CLEMENTE, 2009). ${ }^{8}$ Nos últimos anos houve relativo aumento de pesquisas dedicadas à sua memória no tempo presente (ARAÚJO SÁ; RAMOS FILHO, 2018). Um dos problemas mobilizadores tem sido, sem dúvida, pensar como a memória do cangaço é forjada, contestada, negociada e até neutralizada como elemento de identidade que integra a "Invenção do Nordeste" enquanto objeto de saber e espaço de poder através de "práticas e discursos regionalistas em torno da arte, da literatura, da política, de movimentos sociais e culturais que vão conferindo-Ihe toda uma dizibilidade e visibilidade ao longo do século XX" (ALBUQUERQUE JR, 2011, p. 130).

Embora o cangaço tenha acabado há décadas, sua memória sobreviveu em diferentes meios culturais, tais como objetos, oralidades, locais, folhetos de cordel, artesanato, periódicos, fotografias, livros, filmes, músicas etc. que, por sua vez, propiciaram demais tipos de conservação, transmissão e ressignificação. Ao longo dos anos, essa memória foi trabalhada, manipulada e abusada com vários interesses, de forma que ela, a priori mais rural, regional e popular, ultrapassou em muito as fronteiras do sertão nordestino em caráter de repercussão. O estudo do tempo presente a partir da “cultura da memória” é um dos caminhos para elucidar tais nuances.

A própria constituição da história da memória tem profunda relação com determinadas marcas do tempo presente. Sobre as suas peculiaridades, Henry Rousso (1996, p. 95) pontua que "essa história tem sido quase sempre uma história das feridas abertas pela memória, não sendo no fundo senão uma manifestação, entre outras, das interrogações atuais e palpitantes sobre certos períodos que 'não passam'”. Sabendo que o tempo presente é o tempo da experiência vivida" (BEDARIDA apud PEREIRA, 2011, p. 58), nota-se ainda mais que a pesquisa histórica, ao debruçar-se diante disso, convive num

\footnotetext{
${ }^{8}$ Muitas colocações sobre esse assunto no texto são tributários do estudo do referido autor.
} 
“Da praça pública ao palácio”: a atuação da imprensa cearense na cultura da memória do cangaço (19821995)

“tempo com testemunhas vivas e com uma memória que pode ser a sua”. Assim, o seu objetivo "é ser capaz de produzir a História do nosso próprio tempo, tentando obter uma reflexão que permita recuo relativo", o qual é concedido pela ética da investigação e não pelo tempo transcorrido (ROUSSO, 2009, p. 202 e 209).

Nesse tempo mais próximo, a intensificação memorial relaciona-se ao surgimento, dilatação e expansão globalizada da referida "cultura da memória" (HUYSSEN, 2014). No terço final do século XX, conjuntura de redemocratização no mundo ocidental, há um nítido fortalecimento. Pierre Nora, que já chamou tal período de "Era das comemorações" (NORA, 1992), sugeriu que memória, identidade e patrimônio são as palavras-chave para se entender a consciência histórica no mundo contemporâneo. Em tal cenário, com o incentivo ao direito à memória, dimensão básica das cidadanias que se aspirava construir, uma profusão de "memórias subterrâneas" (POLLAK, 1989), questionadoras em potencial de marcos memoriais oficiais, conquistou força pública, operando a "fragmentação de identidades homogêneas" (HALL, 2011) e reivindicação de “novos patrimônios" (POULOT, 2009) por grupos que não se reconheciam nas heranças antes instituídas.

Não por acaso, os efeitos dessa guinada memorial podem ser notados nas práticas comemorativas. Comparando-se ao paradigma tradicional, houve uma "inversão da dinâmica da comemoração", com padrão nutrido não pela imagem unitária da Nação, mas pela "multiplicidade de identidades de grupos particulares, que se desdobravam na diversidade de eventos dos mais variados matizes e perfis, sem que houvesse critério ordenador e hierarquizador" (GONÇALVES, 2012, p. 28) Um caso emblemático desse debate foram as comemorações ao bicentenário da Revolução Francesa (1989), mas também poderia se incluir nesse espectro o bicentenário da "independência dos Estados Unidos da América" (1976) ou o "quincentenário da descoberta da América" (1992). Nas comemorações brasileiras, a assertiva teria ressoado na década de 1980 , durante as comemorações aos centenários da Abolição da Escravidão (1988) e da Proclamação da República (1989), bem como na década de 1990, com as comemorações ao tricentenário de morte de Zumbi dos Palmares (1995), aos centenários da Guerra de Canudos (1993- 
1997) e ao centenário de nascimento de Lampião (1997-1998), que "fizeram emergir discursos antes marginalizados no contexto da história oficial” (ARAÚJO SÁ, 2011, p. 32).

Alguns vetores desse sugerido "boom" memorial (WINTER, 2006) são os seguintes: a descentralização de ações e representações que não estão mais restritas a poucas instituições, como Estado, Igreja e Escola; o direito à memória, mobilizado sobretudo por grupos marginalizados que, ao terem tido suas memórias relegadas por marcos oficiais, ressaltam um desejo de tradição que também está ligado à luta por poder (HEYMANN; ARRUTI, 2012); a expansão dos suportes da memória com o desenvolvimento das tecnologias da informação que viabilizaram maior registro, produção e difusão; o interesse do público, a demanda por bens culturais e os tipos de consumo cultural que fomentam a espetacularização; a ruminação de eventos traumáticos, responsáveis por incitar o dever de memória - compromisso em não esquecer tais passados - a fim de que se consiga extrair alguma lição da dor (HARTOG, 2013).

Nesse período, em que o regime de historicidade presentista é mais vivenciado, François Hartog considera que as relações subjetivas com o tempo se alteraram, afinal, "esse futuro não é mais um horizonte luminoso rumo ao qual caminhamos, mas uma linha de sombra que colocamos em movimento em nossa direção, enquanto parecemos patinar no campo do presente e ruminar um passado que não passa" (HARTOG, 2013, p. 245). Esses "passados que não passam" são tipos de passados que as pessoas não querem ou dos quais não conseguem se desvencilhar facilmente, o que geralmente está ligado a memórias dolorosas, por isso o dilema - lembrar ou esquecer - ecoa tão forte em seu debate. Cunhada na segunda metade da década 1980, em meio aos acalorados debates sobre "negacionismo", "revisionismo" e "relativismo", a expressão pertence originalmente a Henry Rousso. Foi usada largamente para referir-se às memórias dolorosas da Segunda Guerra Mundial, na Alemanha e França, mas passou a ser aplicada a outras memórias, como a da União Soviética, na Rússia; do Apartheid, na África do Sul; e das Ditaduras Militares, na América Latina9.

\footnotetext{
9 Para aprofundar o assunto, sugere-se leitura da obra organizada por: VARELA, 2012.
} 
Diante disso, a noção de "temas sensíveis" parece ser mais adequada para abordar outros tipos de passados que causam desconfortos, incômodos e embaraços às narrativas tradicionais da história nacional por suscitarem contas a acertar no presente, mas não figuram necessariamente no contexto supracitado. Uma outra variação importante para a instrumentalização de debates como esse, apontada por Luciana Heymann e José Arruti, acontece em torno da noção “dever de memória”. Advinda do contexto francês, o termo remete à ideia de um "imperativo social manifesto em relação a passados sensíveis por indicar obrigação de lembrá-los como forma de reparação ao silêncio, à invisibilidade ou ao sofrimento das comunidades que os vivenciaram" (HEYMANN; ARRUTI, 2012, p. 136). Em abordagem do caso brasileiro, os autores sinalizam como a noção de "deve de memória" seria deslocada para algo como uma noção de “desejo de tradição", em que estão em jogo novas formas de "autoidentificação das quais decorrem as lutas por manter vivas memórias particulares, conquistando para elas espaço no discurso histórico oficial, por inclusão sem homogeneização e por representação política e direitos" (HEYMANN; ARRUTI, 2012, p. 137).

No Brasil, a atribuição da expressão “tema sensível” à escravidão negra africana e ao genocídio dos povos originários do continente tem sido relativamente comum (QUADRAT, 2018, p. 213). Mas, salvo às devidas proporções, uma tríade composta por Padre Cícero, Antônio Conselheiro e Lampião, símbolos identitários da região Nordeste do país, fazem parte de um conjunto de experiências sertanejas cujos passados têm igualmente maiores dificuldades de passar, por serem marcadas por situações debilitantes e/ou politicamente conflitivas. No caso do cangaço, a prática do dever de memória costuma alertar para um descaso do Estado, que teria sido o principal responsável por alguns sertanejos terem se tornado cangaceiros, e uma denúncia da violência estatal cometida após a morte dos cangaceiros, por terem feito das cabeças decepadas troféus macabros da repressão e não terem também cobrado uma sepultura devida (RAMOS FILHO, 2016). Nesse âmbito, os sujeitos tentam extrair alguma lição do passado, por isso discutem os fatores como latifúndio, seca e fome que teriam dado origem ao cangaço, para que casos assim não mais aconteçam. 
A análise do tema sensível do cangaço a partir da noção do dever de memória é, sem dúvidas, fundamental. Todavia, na própria reflexão aqui mobilizada, importa mais a variação da noção entendida como desejo de tradição. Sobre outras formas de investigação da memória no tempo presente, as provocações de Régine Robin apresentam caminhos instigantes. Robin (2016, p. 26) busca assumir uma estética e ética da responsabilidade sem cair na armadilha da dicotomia entre "dever de memória" e “trabalho de memória”, com intuito de produzir um saber acerca dessas "memórias feridas, precárias, de passados impensados, insensatos, que nos habitam sem que saibamos e que retornam". A necessidade de "afastar-se das categorias patológicas e procurar outros caminhos para identificar o que está em jogo nos problemas da memória, de sua história, de seus trajetos, de suas transformações-deformações" é estímulo, portanto, para entender "novas configurações, rearranjos das narrativas que as sociedades contam ou se contam sobre seu passado" (ROBIN, 2016, p. 37, 38). Por conseguinte, Robin ressalta que prefere falar de ritmos da memória, de sua tecelagem e de seu desfilamento, o que contribui de forma mais fluída no estudo de outras questões, como aquelas que fazem morada na seara do patrimônio. ${ }^{10}$

Nessa perspectiva, o campo do patrimônio é um fértil ambiente para investigar os rearranjos das narrativas que uma sociedade produz sobre o seu passado através da atribuição de diferentes valores aos lugares, às práticas e aos objetos. Para Dominique Poulot (2009, p. 9), o fim do século XX assistiu ao "reconhecimento de novos patrimônios que resultam de uma profusão de esforços públicos e privados em favor de múltiplas comunidades". Nessa inclinação, Gilberto Nogueira indica como os debates foram acompanhados de mudanças conceituais "elaboradas em perspectiva com os anseios de novos sujeitos históricos que entraram em cena e forjaram a necessidade de se repensar os silêncios e os ocultamentos, assim como o que deve ser protegido, valorizado e repertoriado" (NOGUEIRA, 2014, p. 52). No âmbito desses outros tipos de patrimônios, ressalta-se a importância das ideias de John Tunbridge e Gregory Ashworth sobre o dito

\footnotetext{
10 Agradecemos ao parecerista anônimo que chamou atenção para a relevância de destacar as transformações que incidem sobre os usos sociais do cangaço em nova conjuntura definida pelo "dever de memória", o que trouxe à tona a revisão do debate sobre a instrumentalização da noção em seus diferentes embaraços e perspectivas.
} 
patrimônio dissonante, para notar a "contestação inevitável do patrimônio em função das discordâncias quanto ao seu valor" (ASHWORTH; GRAHAM; TUNBRIDGE, 2007, p. 36). Ao refletir sobre dissonâncias de memórias difíceis - desprovidas de glamour histórico ou dolorosas - Cristina Meneguello (2014, p. 46) comenta como elas trazem constante indagação: “o que ocorre quando não se quer ou não se pode preservar o passado?”. 0 incômodo que suscitam certamente está relacionado às demandas por reparação que também atingiram as políticas públicas de preservação.

Foi nessa conjuntura, de emergência de memórias marginalizadas da cena oficial como a indígena, a negra e a sertaneja -, que o tema do cangaço entrou mais em pauta. É perceptível um movimento nordestino que, ao ser incentivado por interesses que circulam entre desejo de tradição, dever de memória e consumo cultural, questiona estigmas, descasos e censuras que se considera historicamente impostos, redefinindo o seu lugar nos quadros das identidades espaciais. Alguns marcos dessa revisitação memorial ao cangaço são: a exibição televisiva nacional do seriado "Lampião e Maria Bonita", pela Rede Globo, na década de 1980; a criação da Sociedade Brasileira de Estudos do Cangaço (SBEC), na década de 1990; e a consolidação da Missa do Cangaço, na Gruta de Angico, na década de 2000.

Contudo, não se pode perder de vista as contendas acionadas, sobretudo, pelas vítimas do cangaço e seus descendentes, que se incomodam com o que dizem ser “glorificação”, “endeusamento” e “apologia” do cangaço. “As ressignificações, valorações e negociações dos conflitos da memória do cangaço são, por sua vez, fortemente manifestados por premissa do início dos anos 1990: 'Lampião não é nem bandido, nem herói, ele é história!"” (RAMOS FILHO, 2016). No contexto de redemocratização que abordamos mais extensamente, aponta-se como as comemorações ao cinquentenário de morte de Lampião, em 1988, foram basilares. O tombamento estadual da Gruta de Angico, no ano seguinte, é um exemplo sintomático dos acordos e disputas envolvendo o tema, sobretudo de como o "dever de memória" foi usado na situação de busca por preservação do local. (RAMOS FILHO, 2018b).

Em muitas cidades sertanejas, o desenrolar de uma série de iniciativas responsáveis pela sobrevivência dessa memória é impulsionado pelo desejo de legitimar 
as histórias dos próprios municípios, propor novos debates para se extrair lição desse passado controverso discutindo problemas sociais da região e agenciar apropriações de consumo por iniciativas públicas e privadas. O uso desse passado pode ser entendido igualmente como fruto dos processos de urbanização das cidades que levaram a uma “governança” (HARVEY, 2005) - coalização de setores entre administração pública e parceiros privados - a assumir caráter empreendedor, possibilitando a criação de projetos que objetivavam fazer os locais serem atrativos para o consumo cultural, por meio sobretudo do turismo.

Essas cidades nordestinas, semelhantes nas desigualdades sociais e na herança da passagem do cangaço em seu território, entraram em concorrência por tal memória, construindo determinadas tradições identitárias: Serra Talhada-PE, “Berço de Lampião”, por conta do nascimento de Virgulino; Triunfo-PE, "Lampião de Triunfo", em razão da ideia de que o cangaceiro tinha boa convivência no local; Floresta-PE, terra dos "Perseguidores de Lampião", por ter muitos descendentes de volantes; Piranhas-AL, “Elogio da Traição”, por ter sido lá planejado o último e vitorioso ataque das volantes a Lampião; Mossoró-RN, "Resistência ao cangaço", pelo discurso de ter sido a única a conseguir expulsar Lampião; Paulo Afonso-BA, “Terra de Maria Bonita”, em virtude do nascimento no local desta cangaceira; Poço Redondo-SE, "Capital do Cangaço", por ter sido local originário de muitos cangaceiros que ingressaram nos bandos de Lampião. Assim, faz sentido dizer que Lampião é uma forte marca que identifica, ressignifica e vende o Nordeste ${ }^{11}$.

No município de Juazeiro do Norte-CE, cuja imagem recorrente é do lugar onde Lampião recebeu "patente de Capitão", algumas iniciativas que contemplam tal memória são perceptíveis. Trata-se das ações que promovem a revitalização da tipografia "Lira Nordestina” (1988), a constituição do "Centro de Cultura Popular Mestre Noza" (1983) e a criação da "Fundação Memorial Padre Cícero" (1988). Por serem centros de convergência cultural entre artistas populares, intelectuais e diferentes interessados na cultura nordestina, possibilitam transmissão mnemônica do cangaço, mesmo que de

\footnotetext{
${ }^{11}$ Frase inspirada no livro de Mariana Cisneyros, Lampião, a marca que vende o Nordeste, de 2007.
} 
forma indireta, como acontece na sua materialização que ganha vida através do artesanato.

Na região nordestina, existem inúmeras apropriações. Obviamente, o rápido mapeamento apresentado até aqui não contempla todas as interfaces envolvidas. Entretanto, essa busca memorial constitui singular amostra de como o fenômeno situa-se no tempo presente, provavelmente inserido no corolário do aforismo "um passado que não passa", embora seja mais prudente considerá-lo como um tema sensível do Nordeste brasileiro, por carregar em seu bojo muitos impasses, como o dilema - lembrar ou esquecer? Desse cenário surgiu uma série de atribuições de valores a locais, bens e práticas que convergem em direção à construção direta ou indireta de um patrimônio cultural nordestino reivindicado, dissonante e contestado. O patrimônio é reivindicado porque suscita valorações que se distanciam da definição tradicional de herança cultural; dissonante porque há grande dissenso em torno do seu valor na identidade nordestina, seja em contestação ao seu valor enquanto elemento identitário ou por falta de acordo quanto a algumas valorações; e contestado porque há questionamentos à vinculação identitária entre o fenômeno e a região (RAMOS FILHO, 2018a). As premissas instigam porque servem como baliza para análise de demais questões ao longo do tempo e no desdobramento do espaço.

\section{Uma governança na cena pública cearense: empreendedores da memória em ação entre a política pública e a imprensa}

$\mathrm{Na}$ busca de compreender o fortalecimento da memória do cangaço na cena pública cearense, percebe-se a necessidade de perceber como certas "governanças" passaram a se apropriar do tema em suas práticas culturais. Eis uma forma de notar os “empreendedores da memória” (JELIN, 2002, p. 48) que fizeram usos desse passado por meio de variantes de um desejo de tradição, em cenário de acordos e conflitos, ao serem geradores de projetos, de novas ideias e de outras expressões da memória, transmutando-a em virtude de variados interesses e tornando-a uma pauta pública recorrente. 
Observa-se que, no interior do Ceará, em Juazeiro do Norte, diferente de outras cidades nordestinas que se apropriaram dessa memória do cangaço, promovendo até construção de museus específicos para o fenômeno, não houve investimentos de grande envergadura, talvez porque foram dirigidos para alguém por quem os juazeirenses tinham maior apreço - o Padre Cícero. As pesquisas em torno da sobrevida memorial do cangaço, contudo, não precisam se restringir aos lugares por onde cangaceiros passaram.

Ao longo do estudo em que essa pesquisa foi desenvolvida, notamos que um dos maiores empreendimentos veio da capital cearense, com a gestação de uma governança preocupada em modernização através dos usos da cultura que, transversalmente, teve grande responsabilidade pela consolidação do tema na cena pública, tanto no interior quanto na capital, visto que há uma integração entre as duas áreas. A citada governança é formada pela principal entidade cultural do estado, a Secretaria de Cultura do Estado do Ceará (Secult-CE), e um parceiro privado, o Grupo de Comunicação Jornal O Povo. Vejamos alguns aspectos das políticas culturais em sua relação com o cangaço para compreendermos tal formação.

A Secult-CE foi criada no ano de 1966. Inicialmente, os intelectuais que a geriam interessavam-se por peculiaridades relacionadas "à tradição dos homens das letras cearenses" (OLIVEIRA, 2014), portanto, ações de preservação da memória do cangaço passaram ao largo da sua atuação. Em meados da década de 1970, quando houve uma virada institucional nos trabalhos da Secretaria em função da criação do Centro de Referência Cultural do Ceará - CERES, percebem-se mudanças na valoração do tema. O CERES, enquanto núcleo de pesquisa, estudo e registro da memória da cultura tradicional popular, atuante sobretudo no Cariri cearense, envolveu-se na preservação do saberfazer de artistas populares e de seus respectivos trabalhos - artesanatos, folhetos de cordel, festas e folguedos populares -, o que ocasionou conservações transversais da memória do cangaço, por ser um tema recorrente em tais manifestações (NOGUEIRA; RAMOS FILHO, 2016). Todavia, o seu fortalecimento na cena pública aconteceu ao longo da década de 1990, em virtude da reestruturação nas políticas culturais do autodenominado "Governo das Mudanças", que apropriou-se da cultura com a intenção de modernizar a imagem do estado e reforçar sua economia no mercado globalizado, 
pois foi nessa esteira que houve financiamento substancial de filmes, exposições e livros do cangaço.

O “Governo das Mudanças" no Ceará teve diferentes fases. Entre 1987 e 2002, os governadores foram os políticos Tasso Jereissati (1987-1990 / 1995-2002) e Ciro Gomes (1991-1994). No momento analisado, a Secult-CE teve como secretários/as, respectivamente, Barros Pinho (1988), Violeta Arraes (1988-1990), Augusto Pontes (19911992) e Paulo Linhares (1993-1998). Alexandre Barbalho comenta que "em um primeiro momento, o governo Tasso não percebeu o papel que a área cultural poderia desempenhar no projeto de se estabelecer a imagem de Ceará Moderno”. Contudo, houve valorização posterior da área no projeto mudancista e, "quando isso ocorreu, ou seja, quando se compreendeu a capacidade da cultura em agregar valores de distinção, ela passou a receber atenção nunca antes vista no Ceará" (BARBALHO, 2005, p. 49).

A reestruturação do lugar da cultura nas políticas públicas foi gradual. Um de seus momentos mais expressivos ocorreu na gestão de Paulo Linhares, com a implementação do Plano de Desenvolvimento Cultural (1995-1996). Diferentemente das "políticas de balcão”, desenvolvidas sem planejamento prévio, o plano "estabelecia estratégias gerais para a atuação da Secult-CE, bem como seus objetivos específicos e táticas a serem utilizadas" (BARBALHO, 2005, p. 209). Basicamente, tentava-se implementar política de criação de uma "indústria cultural cearense que deveria modernizar o campo cultural local, inserindo-o no global, e, ao mesmo tempo, criar um efeito de imagem que diferenciaria o projeto cearense" (BARBALHO, 2005, p. 269). Dessa reestruturação, gestou-se o expansivo financiamento de algumas ações, megaeventos e construções de destaque na seara cultural, como a Bienal Internacional do Livro, o Cine Ceará (o Festival Ibero-americano de Cinema) e o Centro Dragão do Mar de Arte e Cultura

Para a concretização dos projetos, as parcerias com o setor privado, mediadas através da Lei Estadual de Incentivo à Cultura (n. 12-464/1995), foram imprescindíveis. A Lei Jereissati, como ficou conhecida, mobilizou a classe empresarial local para investir na cultura utilizando argumentos práticos, como propor uma dedução de até 2\% do Imposto de Circulação de Mercadoria e Serviços (ICMS) aos contribuintes que financiassem os projetos estatais, mas valendo-se igualmente de argumentos simbólicos, através de 
materiais de divulgação repletos de frases de efeito que buscavam legitimar a ideia de que a "cultura é um bom negócio", como: "Menos imposto, mais cultura”; "A arte de pagar menos imposto, usando apenas a lei”; "Muita gente entrou pra história ajudando a arte e a cultura. Agora, você pode ganhar dinheiro fazendo o mesmo" (CEARÁ, 1996).

A maioria dos empresários, os quais eram comparados com os mecenas da época do Renascimento, comprou a ideia. No conjunto de parceiros privados, figura o Grupo de Comunicação O Povo. Embora não apareça explicitamente na lista dos mais altos investidores, o grupo tem papel crucial no circuito, por ser uma empresa alinhada aos setores interessados e atuar como espaço de convergência, divulgação e legitimação de projetos de desenvolvimento econômico via cultura.

Os projetos incentivados pela Lei Jereissati contemplavam diversas áreas: 1. Música; 2. Artes Cênicas; 3. Fotografia, Cinema e Vídeo; 4. Literatura, inclusive de cordel; 5. Artes Plásticas e Gráficas; 6. Artesanato e Folclore; 7. Pesquisa Cultural ou Artística; 8. Patrimônio Histórico e Artístico; 9. Filatelia e Numismática; 10. Editoração de Publicações. Entretanto, o setor que recebeu o maior investimento foi a indústria audiovisual, por ser vista como "setor de ponta da indústria do século que se avizinhava, mercado que será desenvolvido pela economia da informação e comunicação" (BARBALHO, 2005, p. 269). No eixo de criação, produção e divulgação do audiovisual previsto nos planos de desenvolvimento, um dos primeiros filmes contemplados foi Corisco e Dadá (1996), do cineasta cearense Rosemberg Cariry, que visava retratar a trajetória dos referidos cangaceiros.

Foi nesse contexto que a memória do cangaço fortaleceu-se no cenário público cearense e o estado entrou na disputa, não tanto pelo seu legado mnemônico entre as cidades nordestinas, mas pela sua apropriação transversal, como fonte impulsionadora de investimentos públicos e privados. Baseado nisso, propomo-nos a realizar, adiante, uma microdiscussão para problematizar esse processo de revisitação. Para tanto, analisamos a atuação de instituição privada que, ao longo dos anos, tornou-se um dos empreendedores de memória cearenses mais significativos do assunto: o jornal O Povo.

$\mathrm{Na}$ imprensa cearense do tempo presente, os dois jornais de maior circulação são 
O Povo e Diário do Nordeste. O interessante é entender como esses periódicos vão se fazendo ao longo dos anos em relação à memória do cangaço, analisando aspectos de linhas editorais e notando singularidades de cada contexto. Assim, a proposta fundamental é compreender a historicidade dos jornais em suas configurações políticas e sociais, sobretudo, após a redemocratização, quando a grande imprensa procurou alinhar-se aos princípios ditos modernos no mundo contemporâneo, vinculados à globalização, à democracia e ao consumo, o que implica analisar sua própria materialidade.

Conforme colocam Heloisa de Faria Cruz e Maria Rosário da Cunha Peixoto (2007), devemos entender as narrativas dos jornais sobre acontecimentos não como um dado espelhos informantes da realidade do contexto, mas como força social ativa que atuam como ingredientes constituintes da realidade, dentro de uma trama histórica na qual se constituem, pois não apenas informam detalhes do que reportam: eles formam determinadas opiniões públicas sobre o que se passa. Daí a importância de perceber o funcionamento do seu projeto gráfico, relativo à organização de conteúdo nas diversas partes e seções no interior do periódico, bem como a sua produção e distribuição, que nos remetem aos grupos produtores, aos públicos leitores e às redes de comunicação constituídas. A questão é que todas essas engrenagens propõem uma maneira de ler orientando, mediando e controlando abordagens - associada à linha editorial do periódico. Por isso a ideia de que o seu dito pluralismo é mais de opinião do que de fato.

O itinerário da análise demanda resposta para algumas indagações: qual a historicidade dos periódicos cearenses? Quais as correlações sociais e políticas que os envolvem e como são suas relações com outras instituições, sobretudo, a Secult-CE? Como aconteceu a reestruturação de suas linhas editoriais no tempo presente? Em quais partes, cadernos e editorias o tema do cangaço costuma aparecer na década de 1980 e $1990 ?$

O jornal O Povo foi fundado em 1928 por Demócrito Rocha. O periódico, vinculado à Fundação Demócrito Rocha e pertencente ao Grupo de Comunicação O Povo, é um dos mais antigos e de maior circulação no estado cearense. Ao longo dos anos, passou por diferentes linhas editoriais, mas aquela com maior incidência no tempo presente veio de 
reestruturação gestada no final da década de 1980, em sintonia com a formulação da sua Carta de Princípios de 1989 (ANTUNES, 2002). Destaca-se a visão construída sobre certos princípios, tais como: "Regionalidade" - defesa das aspirações e dos valores da região, prolongamento maior da nacionalidade, (...); "Cultura e Educação" - representação de valores solidários (...), com a consolidação da consciência crítica e da cidadania; "Modernidade" - importante em um processo contínuo de renovação das formas de pensar e de agir, intensificadas com os anseios e as aspirações da sociedade, como o respeito indispensável pelas opiniões sobre os fatos e as ideias. O jornal teve outra importante mudança editorial em 1997, quando instituiu o Conselho de Leitores, formado por representantes da sociedade civil, com intenção de promover ambiente no qual avaliações, críticas e sugestões de pautas pudessem acontecer.

Depois dessas reestruturações, a composição do jornal seguiu amplamente a seguinte organização gráfica: Caderno A - Política, Nacional, Opinião, Polícia, Esportes, Internacional; Caderno B - Vida e Arte; Caderno D - Economia; Caderno E - Ciências e Saúde. Nos assuntos culturais, cabe sinalizar que o antigo Segundo Caderno passou a ser o "Vida e Arte", formado para praticar um "jornalismo cultural de reportagem com investigação dinâmica e inteligente". Para os finais de semana, conta com o suplemento cultural "Sábado", destinado a "matérias que trazem perfis, lançamentos ou tendências da literatura no país e no mundo, no qual se busca mostrar tanto o ponto de vista do acadêmico quanto a opinião de pessoas que não passaram pela Universidade". Na maior parte das vezes, o cangaço aparece nas páginas de cultura. Além disso, ressalta-se que, em meados dos anos 1990, o jornal se aproximou bastante da Secult-CE, em função das leis de incentivo à cultura, o que teve impacto na forma de o periódico abordar o tema.

O jornal Diário do Nordeste foi fundado em 1981 por Edson Queiroz. O periódico, que integra o conglomerado de empresas Sistema Verdes Mares, pertencente ao Grupo Edson Queiroz, tornou-se um dos jornais com maior circulação do estado atualmente e um dos grandes concorrentes do O Povo (MARCO..., 2006). Sua diferença é que traz maior abordagem do interior através de sucursais em vários municípios cearenses e algumas em outros estados nordestinos. Após a reestruturação de sua linha editorial no tempo presente, a composição gráfica passou a ter basicamente o seguinte padrão: $1^{\circ}$ 
Caderno: Chamadas, Opinião, Política, Nacional, Internacional, Interior, Economia; $2^{\circ}$ Caderno - Grande Fortaleza: Reportagem, Cidade, Bairros, Polícia, Esporte; $3^{\circ}$ Caderno: Reportagem, Roteiro, Sociedade, Literatura, Variedades, Televisão. Os assuntos culturais, que antes ficavam no Segundo Caderno, passam para o Terceiro, cujo subtítulo é "Estilo de Vida, Cultura e Lazer". Nos finais de semana, distribui o suplemento cultural chamado "Cultura". O tema do cangaço costuma aparecer nas páginas culturais, mas também pode figurar na editoria do Interior com abordagem mais crítica ao assunto. Apesar de divulgar alguns projetos estatais, não tem tanta vinculação com a Secult-CE, pelo menos em relação às ações ligadas ao cangaço.

\section{Operações midiográficas da memória: (in)formações públicas do cangaço}

O estudo da "operação midiográfica" dos jornais em cena é fundamental não só para perceber como informam acontecimentos ao mesmo tempo em que formam significado para a memória do cangaço referente às identidades nordestinas, mas para notar como suas bases editoriais são construídas acerca do tema. Uma forma de “entender a engenhosa mobilização de instrumentos na construção de evento memorial através de narrativas de revisão, reflexão e reavaliação do passado", as quais envolvem jornalistas, intelectuais, escritores, especialistas, testemunhas etc. (MENEZES, 2014, p. 231-232 $)^{12}$. Para isso, abordamos três momentos importantes, a partir das matérias do 0 Povo e do Diário do Nordeste: o momento do seriado "Lampião e Maria Bonita”, através da série de reportagens "Lampião agora é mito" (1982) e da notícia "Cozinheira de Lampião" (1982); o momento do cinquentenário de morte de Lampião, por meio da notícia “Lampião - luz da revolta social” (1988) e da notícia “Pesquisador revela face cruel de Lampião" (1988); o momento da reestruturação das políticas culturais cearenses, com o dossiê "Lampião: o mito do bandido e do herói cangaceiro" (1993) e a notícia "Livro desmistifica lendas do cangaço" (1995).

\footnotetext{
${ }^{12}$ A autora da tese sinaliza que os "eventos emblemáticos do tempo presente foram elaborados em tripla constituição: evento midiático, construído diariamente a partir de notícias; evento memorial, elaborado em narrativas "revisão", "reflexão" e "reavaliação" do passado; e acontecimento histórico historiográfico, na medida em que, a partir de um dado momento, tornou-se objeto de reflexão na produção acadêmica" (MENEZES, 2014).
} 
No terço final do século XX, diversas memórias do cangaço, anteriormente silenciadas em discursos de caráter oficial, chegam ao conhecimento público. $\mathrm{Na}$ imprensa, o assunto costuma despontar por conta de publicações de livros, exibição de filmes, exposições artísticas e entrevistas com ex-cangaceiros, familiares, sertanejos, artistas e intelectuais. No começo da década de 1980, a exibição nacional da minissérie histórica "Lampião e Maria Bonita", de Aguinaldo Silva e Doc Comparato, entre 26 de abril e 5 de maio de 1982, pela Rede Globo de Televisão, expandiu significativamente o interesse pelo tema em vários lugares do país. No período, os jornais apresentaram-no concedendo espaço para a valoração de certas memórias. É o que sugerem as notícias “Cozinheira de Lampião” (1982), do Diário, e “Lampião agora é mito” (1982), do O Povo.

O recém-criado Diário produziu matérias com caráter esporádico. Foi o caso de “Cozinheira de Lampião”, publicada na sessão Variedades, em 4 de fevereiro de 1982. Embora tenha sido publicada antes da exibição da minissérie, a notícia interessa-nos à medida que ajuda a vislumbrar o contexto. A matéria é sobre a idosa Quitéria Guimarães, natural do interior de Pernambuco, que diz ter sido a cozinheira predileta de Lampião na fazenda de um dos seus coiteiros, quer dizer, aqueles que ofereciam guarita aos cangaceiros em determinadas ocasiões. O jornal apresenta-lhe da seguinte forma:

Cega de um olho e com uma das pernas paralisada, em razão de doença reumática, com 70 anos, Quitéria Guimarães de Araújo é dona de um cérebro privilegiado. Com esta idade lembra-se nos mínimos detalhes de vários momentos que passou atendendo Lampião e seu bando. (COZINHEIRA..., 1982, p. 28. Grifo nosso)

Nesse trecho, a memória da testemunha do cangaço, que teria se encontrado poucas vezes com Lampião, é valorada como importante para conhecer variadas características do fenômeno. O caso não era isolado. Em quase todo lugar, parecia existir alguém com algo para contar e alguém com interesse em escutar. No entanto, alguns consideravam que tais memórias não passavam de falácias produzidas para aparecer na mídia. Pode-se dizer que esse foi um dos fatores que o jornal O Povo mobilizou para 
justificar a produção de uma série de reportagens com o sugestivo título de "Lampião Agora é Mito".

A série de reportagens “Lampião...”, produzida pelo jornalista Fenelon Almeida, que trabalhava no departamento de pesquisa do jornal, tinha intenção de apresentar narrativa que esclarecesse temas polêmicos. Foi publicada semanalmente entre 19 de julho e 27 de setembro de 1982, no Segundo Caderno do O Povo, e em periódicos de outros estados nordestinos. A série foi dividida em 11 partes, que se desdobravam em informações sobre o cangaço, os cangaceiros, os lugares por onde os bandoleiros passaram e a sua apropriação mnemônica por muitos indivíduos. Na primeira reportagem, relata-se como o assunto figurava em diferentes ambientes sociais e parte das ditas polêmicas:

Hoje, é moda falar em cangaceiro. Lampião e Maria Bonita estão sendo novamente levados ao noticiário da imprensa e da radiofonia, não com a mesma intensidade de outros tempos, mas com a vantagem de entrevistas ao vivo e seriados na televisão. O cordel e a música popular, depois de muitos anos de silêncio, também voltaram a focalizar o passado de Lampião e seus comparsas, contando em versos não mais as diabruras, as maldades e as perversidades, os assaltos e as depredações praticados pelos 'facínoras', pelos 'celerados' de antigamente, mas, sim, narrando, hoje, os feitos 'heroicos' de tenentes e capitães do cangaço (...). (ALMEIDA, 1982, p. 1b. Grifo nosso)

Diante da guinada, apresentar um parecer que fosse legítimo perante a opinião pública requeria investimento. $O$ interesse do jornal na cruzada parece ter sido incitado tanto por Fenelon de Almeida, que já havia realizado reportagens menores sobre o tema com repercussão positiva, poucos anos antes, e tinha publicado mais recentemente ainda livro sobre o cangaceiro Jararaca, quanto pela empresa jornalística, ao perceber que uma investida bem-sucedida poderia trazer ao periódico uma ampliação de credibilidade em nível regional. Nessa diligência, Fenelon afirmava que tudo relacionado ao cangaço não deveria "encerrar-se com simples afirmativas e meros desmentidos, ficando o leitor, o ouvinte e o espectador mergulhados em curiosidades e afogados em dúvidas, sem saber em quem acreditar (...)". Para contornar isso, dizia informações do seguinte tipo: 
(...) saí à procura de provas e tentei encontrá-las junto a diversas pessoas idôneas. Estive em Juazeiro, Crato e Barbalha, no Ceará; fui a Picos e a Valença, no Piauí, onde encontrei Ezequiel; estendi viagem até a cidade de Salvador, Bahia, onde conversei longamente com Dadá, excangaceira, viúva de Corisco, lugar-tenente de Lampião, por mim considerada a Enciclopédia Viva do cangaço no Nordeste. (ALMEIDA, 1982, p. 1b. Grifo nosso)

O jornalista tentava se legitimar dizendo que as viagens feitas pelo Nordeste tinham possibilitado contato com informantes "confiáveis". Nesse procedimento, também se valora bastante uma memória viva, a da ex-cangaceira Dadá, pois, ao ser uma remanescente do grupo, teria respaldo para "solucionar" polêmicas, daí ser vista como “Enciclopédia Viva do cangaço". Sugeria-se, com essa "retórica testemunhal”, que, diferente de outras pessoas, a cangaceira só falava a verdade. Mesmo assim, sabemos que ela própria não estava totalmente imune às novas imagens do cangaço que estavam em circulação, já que toda reconstrução mnemônica traz consigo as marcas do presente.

Nesse momento, em meio às demandas do assunto que vão ganhando o meio público, os jornais privilegiam memórias de indivíduos que teriam vivido o acontecimento, com destaque para os ex-cangaceiros, na busca de diferenciar o que é "verdade" e "mentira", a fim de se legitimarem na opinião pública. Contudo, outras grandes iniciativas memoriais, como essa do O Povo, não são mais vistas posteriormente, talvez por não ter existido demanda tão extensa quanto a advinda com a minissérie "Lampião e Maria Bonita", dentre outros motivos.

No embalo da redemocratização, aconteceram no estado do Ceará algumas iniciativas em torno do cinquentenário de morte de Lampião. Particularmente, temos notícias de Jornada Cultural realizada no Cariri cearense, na recém-criada Universidade Regional do Cariri (URCA), entre 28 de julho e 9 de agosto de 1988 (QUEZADO, 1988,). Organizado pela própria URCA, o evento contou com programação que tinha basicamente duas frentes: por um lado, foram montadas exposições de objetos do cangaço, livros, cordéis, fotografias e projeção de filmes e, por outro, abriu-se espaço 
para debates diversos com estudiosos do assunto, memorialistas, antropólogos e cientistas sociais.

No cinquentenário, os jornais cearenses informaram tais acontecimentos, mas as notícias que chamam atenção são outras. No caso, trata-se de "Lampião: a luz da revolta social”, do O Povo, e "Pesquisador cearense relata face cruel de Lampião", do Diário, que foram publicadas no dia exato do cinquentenário da morte de Lampião, em 28 de julho de 1988. As notícias são redigidas com clara intenção de formar opinião pública sobre o cangaceiro e, pela contraposição de seus títulos, a divergência da abordagem é nítida. Essas visões antagônicas mostram como o fortalecimento da cultura mnemônica no período estava rodeado de conflitos.

A primeira notícia destacada, escrita por Humberto Pinho Sobreira, no Segundo Caderno do O Povo, insinua saudosismo por Lampião, que aparece como luz orientadora de revoltas sociais. Na narrativa, o jornalista tenta contemplá-lo para além da "versão oficial", por julgar que ela "sempre depende das testemunhas dominantes e do escrivão que está dando plantão na delegacia da História", asseverando que "vale a pena conhecer também um pouco algumas facetas às vezes de caráter popular da vida de Lampião”. No final, após descrever a trajetória de Lampião, destacando suas táticas de combate, diz:

Ao driblar as cercas da existência, no deserto das caatingas, como o 'progresso' da indústria da seca, Lampião aparece ainda vivo na literatura de cordel, onde muitas vezes é feita analogia à figura de Napoleão, que pertencia à Europa civilizada, e fez destruições em cidades e só falam dele como herói. Portanto, por que não se estudar também a figura de Lampião - verdadeira luz de revolta social nordestina? (PINHEIRO, 1988, p. 1, Grifo nosso)

$\mathrm{Na}$ intenção de legitimar sua importância, o jornalista o associa ao imperador francês Napoleão Bonaparte, tratado como um herói no mundo “civilizado". Nativa da literatura de cordel, a analogia é usada para estender essa valorização no meio público e validar a indagação lançada ao final: "por que não estudar Lampião como luz de revolta 
social nordestina?". Nesse texto, a dita revolta acontecia em face do enfrentamento às mazelas sociais, geralmente associadas à omissão do poder público no sertão.

Em contrapartida, a segunda notícia, escrita por Antônio Vicelmo, na seção Variedades, do Diário, enfatiza sentimento de indignação com o cangaceiro, afirmando que muitos o aclamavam como "bandido social, espécie de Robin Hood que tomava dos ricos para distribuir com os pobres". A narrativa, que destaca a obra memorialística do médico Magérbio de Lucena e do representante comercial Hilário Lucetti, usa as entrevistas com os autores para consolidar pergunta que está no centro da notícia: “Lampião: um facínora que reaparece como herói?”. Das impressões dos memorialistas destacadas, surgem perspectivas distintas:

Lampião não pode ser analisado como símbolo do nordestino sofrido, injustiçado, sem-terra, que encontra na violência um meio de sobrevivência (...) Esperamos que, no cinquentenário da morte de Virgulino, nossos filhos não o tenham nunca como um exemplo a ser seguido. Que os sem-terra não o tenham como uma bandeira de luta contra os latifundiários, que os miseráveis não o tenham como símbolo de luta contra os poderosos, que a história não termine por transformálo num herói nacional em detrimento de pessoas santas que dedicaram suas vidas ao bem e à paz. (VICELMO, 1988, p. 6. Grifo nosso)

Em comparação com as notícias precedentes, percebe-se que os jornais não se posicionam simplesmente para valorar ou rechaçar memórias na busca de diferenciar "verdade" e "mentira" do fenômeno. No cinquentenário, ao se debruçarem sobre apropriações feitas por diferentes grupos sociais, mobilizam a opinião pública demarcando o que deve ser estudado e relegado, lembrado e esquecido, homenageado e criticado. Além disso, as notícias são bem circunstanciais, pois não há nenhum tipo de continuidade com as notícias anteriores e qualquer participação em projeto ampliado de empreendedorismo memorial do tema. Destarte, caberia indagar: como esses jornais teriam se posicionado na reestruturação das políticas culturais ao longo da década de 1990 ? 
A metade da década de 1990, devido à reestruturação das políticas culturais, é fundamental para compreensão do lugar da memória do cangaço na cena pública. Nesse período, grande parte das notícias na imprensa sobre o tema relaciona-se à película Corisco e Dadá, que recebia tanto investimento financeiro da Secult-CE, quanto apoio simbólico dos periódicos ${ }^{13}$. Em geral, nota-se mudança enfática na abordagem de suas linhas editoriais, decorrente de fatores internos, haja vista a mudança editorial que gerou editorias específicas para a cultura, e de fatores externos, dada a articulação entre a Secretaria e o empresariado gestor dos jornais. Trata-se de momento em que apresentam forma peculiar de tratar o cangaço através da cultura e, em particular, O Povo torna-se empreendedor da memória desse fenômeno. Evidentemente, as dissonâncias não sumiram.

Duas publicações são sintomas da mudança editorial por trazerem discussões que retomam pontos de publicações precedentes e/ou baseiam posteriores. Por um lado, o jornal O Povo, através da editoria Vida e Arte, produz uma série de cadernos especiais, comemorativos e dossiês com abordagem cultural semelhante, cujo primeiro publicado no formato, o dossiê “Lampião: o mito do bandido e do herói” (1993), é significativo. Por outro lado, percebe-se que o Diário também enfatiza a temática culturalista através do Caderno 3 - Estilo de Vida, Cultura e Lazer -, mas nota-se conflito nos materiais que aparecem no $1^{\circ}$ Caderno - Interior -, por costumarem abordar o fenômeno ressaltando vivências de crueldades, como acontece com a notícia "Livro desmistifica lendas do cangaço" (1995). Com base nisso, questiona-se: como essas mudanças incidiram no fortalecimento da cultura da memória? Para elucidá-lo, temos que aprofundar o contexto de produção das notícias.

O dossiê do O Povo "Lampião: o mito do bandido e do herói” (1993), organizado por Cláudia Albuquerque, editora do Vida e Arte, faz parte do caderno cultural "Sábado". Centralmente, a proposta foi convocar "teóricos para desvendar o mito do herói e bandido que alimenta o imaginário popular nordestino". Para exemplificar esse imaginário, escreve-se nota sobre um cearense de Juazeiro do Norte, João Ferreira da

\footnotetext{
${ }^{13}$ As notícias abordam o filme através de conteúdos que passam por entrevistas com os produtores da película, escolha dos atores convidados, preparativos para filmagens, material utilizado para ambientação histórica e demais formas de divulgação perante o público.
} 
Silva, o João Peitudo, que dizia ser filho de Lampião. Os teóricos convidados são intelectuais da Universidade Federal do Ceará (UFC): Gilmar de Carvalho, professor de Comunicação Social; Régis Lopes, professor de História; e Daniel Lins, professor de Filosofia. Diante do "campo minado onde se debatem as várias faces \& fases do mito", eles foram instigados a cooperar com a demarcação da "exata posição do cangaço na história nordestina".

Por um lado, o dito filho de Lampião, João Peitudo, aparece como alguém que vislumbra os cangaceiros como justiceiros de importância inegável na história da região. Por outro, os intelectuais Gilmar de Carvalho e Regis Lopes pensam como tal imaginário foi estruturado socialmente. Enquanto Carvalho aponta que o cangaço tornou-se “emblema” da cultura nordestina por conta, sobretudo, dos folhetos de cordel, Lopes indica que a intelectualidade não está imune a isso, pois boa parte do que se escuta advém de tradições historiográficas fundadas em teorias raciais, iluministas e marxistas. Ambos constroem representações nos jornais sobre aqueles que dão sentido ao cangaço, seja do plano popular ou da seara intelectual. Mas, quem figura mesmo no centro da reportagem, é o professor Daniel Lins.

A relação de Daniel Lins com a empresa é crucial para se entender, por sua vez, como o jornal O Povo vai se fazendo enquanto empreendedor da memória do cangaço. $O$ intelectual, que aparecia como docente convidado da UFC, recebe destacada atenção na publicação. Isso está associado ao reconhecimento da sua extensa formação intelectual filosofia, sociologia e psicanálise - e a determinados interesses do jornal, haja vista que ele foi convidado para matérias posteriores. Para entender o caso, comecemos pela análise do próprio dossiê “Lampião...”. Na abertura, o texto "Rei do Cangaço vira objeto de teses na Europa" nota que essa era a situação do pernambucano Daniel Lins, recémchegado à UFC, que tinha ido para a França na década de 1970. Ressalta-se que ele teria iniciado suas pesquisas na metade da década de 1980, as quais se desdobraram na tese de doutorado "Imaginário da Ordem e da Violência no Brasil - estudo de um caso: Lampião e o Cangaço", defendida na Universidade de Paris VII, no sítio histórico da Sorbonne, em 1990. 
$\mathrm{Na}$ reportagem, há inclusive uma entrevista com o intelectual, em que ele é incentivado a relatar motivações de pesquisa, formas de abordagem do assunto e intenções variadas. Sobre isso, Lins diz que, "como toda criança nordestina, tinha um imaginário de Lampião" e que isso levá-lo-ia a trabalhar o "sertão, o Nordeste e a memória oral dos sertanejos". Na via de composição da sua tese, comenta que "tinha a preocupação de fazer algo como uma viagem iniciática e conferir um pouco de visão científica à ideia de herói, não mais a partir do que eu pensava como herói nem do que os militares pensavam como anti-herói”. O seu entendimento de herói parece ser advindo do sentido grego - aquele capaz de realizar grandes façanhas. Em sua abordagem, que tentava entender justamente a heroificação de Lampião na sociedade, alguns pontos são suscitados. Quando convidado a responder "quais seriam então as correspondências mais evidentes entre Lampião e o mito heroico grego?", assim como a comentar demais interesses que o impulsionavam na pesquisa, responde, sequencialmente, da seguinte maneira:

Alguns aspectos não correspondem. Mas veja um exemplo: Lampião tinha medo da polícia. Ele nunca a atacava, só se defendia. Isso é típico do herói grego, que se posiciona não no ataque, mas na defesa. Depois vem o lado doce de Lampião, o lado feminino, normal em todos os homens, que se manifestava notadamente nas roupas que ele criou, aquelas botas maravilhosas que ele fez, o fato de ele costurar, de andar com aquela máquina Singer, hoje num museu. Na visão brasileira, nordestina sobretudo, Lampião seria 'o macho'. Como compreender essa feminilidade de Lampião, que logicamente não passava pelo lado afeminado nem homossexual? A feminilidade de Lampião o integra ao mundo dos heróis. Ela não vai tocar na sua virilidade, mas enaltecer-Ihe o lado lúdico. (CARVALHO, 1993, p. 8b. Grifo nosso)

Parti para uma leitura antropológica, sociológica e até certo ponto psicanalítica do fenômeno Lampião. Cheguei à conclusão de que, quando falamos de Lampião, não falamos de um ser humano, mas de um fenômeno. O homem não existe. Lampião foi uma figura emblemática, tratada o tempo todo como mito, inclusive pelos militares (...). A minha tentativa não foi a de resgatar Lampião, porque não se resgata nada e eu evito essa palavra. Foi sobretudo tirar Lampião da praça pública e levá-lo ao palácio (...). (CARVALHO, 1993, p. 7 e 8b. Grifo nosso) 
No primeiro trecho, as contradições de Lampião que balizavam sua pesquisa ganham destaque. Se, pelo lado do senso comum, o cangaceiro é tomado como representante da virilidade sertaneja encarnada pela expressão do "cabra-macho", pelo lado de sua própria vivência, denota-se lado feminino encarnado por hábitos da vaidade, o qual tornou-se uma marca recorrente nos debates que Lins apresentava publicamente sobre essa parte 'mal-dita' (RAMOS FILHO, 2018c)". ${ }^{14}$ No segundo, o propósito de "tirar Lampião da praça pública e levá-lo ao palácio" chama considerável atenção. No caso, o intelectual trata da sua trajetória, uma vez que teria levado o assunto sertanejo para ser estudado em uma reconhecida universidade francesa. O destaque que fazemos é realizado porque um intuito semelhante, embora com finalidade diferente, passa a atrair o jornal O Povo, num cenário que Daniel Lins teve participação direta nesse deslocamento. Claramente, a reestruturação da linha editorial sobre o cangaço na instituição foi realizada numa interação que contou com diversas pessoas ao longo dos $\operatorname{anos}^{15}$. Mas, nesse momento específico, fica claro que o intelectual foi um articulador central da ligação entre a universidade, o governo e a empresa jornalística.

Daniel Lins chega à UFC como docente convidado em 1994, tornando-se logo em seguida professor efetivo e, depois, integrante de outras instituições. Em 1995, passa a ser articulista do jornal O Povo a convite da família Dummar, que preside a empresa e, em 1996, integra-se à coordenação de editoração da Secult-CE, que, na época, estava sob chefia de seu contemporâneo na Universidade de Paris, o secretário Paulo Linhares. Os convites associam-se ao reconhecimento da sua rede de estudos, que the concedia legitimidade intelectual, e aos interesses das entidades em se modernizarem através da cultura. Com a inserção nessa governança, que vinha valorizando o tema do cangaço, abre-se a possibilidade de novamente "tirar Lampião da praça pública e levá-lo ao palácio". Metaforicamente, a transição liga-se à legitimação dessa memória no quadro estatal cearense.

\footnotetext{
${ }^{14}$ A trajetória das intervenções de Daniel Lins sobre o debate público dessa parte 'mal-dita' do cangaço, sobretudo no decorrer dos anos seguintes, também pode ser conferida na citada referência.

${ }^{15}$ Para citar só os sujeitos que apareceram nas notícias analisadas, temos os jornalistas Fenelon de Almeida, Humberto P. Sobreira e Eleuda de Carvalho, assim como os professores Daniel Lins, Gilmar de Carvalho e Regis Lopes.
} 
Um dos maiores indícios dessa reestruturação da política cultural é a pioneira exposição exclusiva sobre o tema, intitulada “Cangaço - Ética e Estética”, realizada no Centro Cultural do Palácio da Abolição, sede do Governo do Estado, em maio de 1995. Promovida pela Secult-CE, com parte da curadoria de Daniel Lins, a exibição visava “retratar a vida no período do cangaço". Essa mostra, que trazia materiais oriundos de diferentes acervos públicos e privados, teve um alto investimento se compararmos com outras do período. Literalmente, o cangaço tinha chegado ao "Palácio”, mas por motivos pragmáticos. No projeto da exposição, a justificativa é clara: “aproveitar o gancho do filme Corisco e Dadá, do cineasta Rosemberg Cariry, cujas cotas serão lançadas na inauguração da mostra. A mostra exibirá ainda vários vídeos sobre o assunto, além de livros e músicas" (CEARÁ, 1995). Por isso, além de a exposição reunir objetos diversos, fotografias e obras artísticas do cangaço, contava tanto com objetos que iam desde autênticos fuzis, bacamartes e punhais até réplicas de bornais, moringas, cartucheiras, sandálias currulepe do cangaço, quanto com figurinos, adereços e acessórios criados para o filme ${ }^{16}$.

No período, os jornais fazem cobertura similar da exposição, destacando as articulações realizadas para a montagem, a proposta do projeto e as intenções do curador Daniel Lins: “mostrar o lado humano do "herói de mil facetas"”17. Menciona-se como o intelectual "lamenta que a figura não seja tão valorizada no país quanto é internacionalmente", o que decorreria do "medo de assumir que a cultura do pobre é, na verdade, riquíssima, e do fato de isso ir contra o discurso oficial da história". Sinaliza que “para se entender o lado humano da violência é preciso transcender a história linear”. Por sua vez, Lins buscou transgredir ressaltando aspectos éticos e estéticos que apontam como as roupas, os acessórios e os utensílios do cangaço "têm um estilo próprio", algo

\footnotetext{
${ }^{16}$ A exposição teve financiamento de 10 mil reais, o que possibilitou montá-la com as coleções particulares de Frederico Pernambucano de Melo, José Ribamar Lopes, Graziela Barroso, Gilmar de Carvalho e Peregrina Capelo Cavalcante, bem como com acervos do Museu Histórico do Crato, Museu do Ceará, Aba Film e Cariri Reproduções. Na gama de projetos da Secult-CE referentes a exposições, outras financiadas no ano foram: "As Caras do Ano" - exposição fotográfica de personalidades da revista Caras - 6 mil reais; "Albrecht Dürer e Gravadores Cearenses" - exposição do artista Albrecht Dürer com participação de gravadores cearenses - 5 mil reais; exposição comemorativa da "Comissão Científica de Exploração 130 anos depois" - 30 mil reais; "Cartier Bresson" - exposição com obras do fotografo francês Cartier Bresson -4 mil e 500 reais.

${ }^{17}$ Sobre a exposição, ver: GALVÃO (1995) e PAULA (1995).
} 
constatado pelas fotos que revelam uma "beleza nobre, elegante e agreste", assim como pelos hábitos que Lampião tinha "de se vestir de modo elegante, possuir coleção de joias, decorar armas com moedas de ouro, perfumar-se com marcas francesas como 'fleur d'Amour' e beber whisky". Para além disso, ressalta outros aspectos ligados ao combate:

A estética do cangaço é um capítulo à parte, que bem simboliza a contradição entre o que é contado pelos livros de história e a realidade. 'Se prestarmos atenção ao vestuário dos cangaceiros, notaremos uma arte quase aristocrática. Lampião era um exímio artesão (...) Então, a ideia de pobreza do cangaço defendida na história oficial não corresponde com a verdade'. (...) E, se a violência do cangaço fascina porque passa pelo belo, também atrai simpatizantes por intrínsecos códigos de ética (...) Lampião e bando atemorizavam mais pela tal ética de honra que ia contra a moral burguesa e as relações dominantes de poder que propriamente pela violência instaurada. (PAULA, 1995, p. $1 \mathrm{~b}$. Grifo nosso)

Partindo dessas premissas, cuja publicação do O Povo, através do Vida e Arte, com o dossiê Lampião, é sintomática da abordagem cultural do tema, ressalta-se que, na contramão desse tipo de matéria, temos uma linha dissonante no Diário, que se manifesta por meio da editoria Interior indicando outras facetas do fenômeno. Diferentemente das valorações suscitadas na exposição “Cangaço - Ética e Estética”, a notícia não assinada “Livro desmistifica lendas do cangaço" (1995), baseada no livro que estava em produção por dois memorialistas, o médico Magérbio de Lucena e o representante comercial Hilário Lucetti, destaca o lado cruel de Virgulino ${ }^{18}$. Sobre a moral dos cangaceiros exibida e comentada na mostra, relacionada às mulheres sertanejas, é apontado que:

A moral de Lampião (...) era de acordo com sua conveniência: exigia respeito pela honra das donzelas e senhoras casadas quando desejava causar boa impressão à comunidade. Em se tratando de filha de coiteiro ou algum amigo rico, redobrava-se em zelo, chegando mesmo a matar

\footnotetext{
${ }^{18}$ Enquanto a maioria das matérias do O Povo tem a presença dominante de intelectuais nos anos 1990, a exemplo de Daniel Lins, algumas matérias do Diário trazem os memorialistas Magérbio de Lucena e Hilário Lucetti, os quais não tinham proximidade com as universidades. Mas, isso não era motivo para falta de convite. No passado cinquentenário de morte de Lampião, por exemplo, também tiveram a obra destacada.
} 
alguns de seus cangaceiros quando estes atentavam contra a honra das pessoas sob a sua proteção. Com a gente miúda, das caatingas, a coisa era diferente. Os defloramentos e as surras eram frequentes (...). (LIVRO..., 1995, p. 16. Grifo nosso)

A peculiaridade dos periódicos no momento de reestruturação da forma de abordagem da memória do cangaço foi o de buscar entender o imaginário do fenômeno a partir de debates com intelectuais, pesquisadores e especialistas. Percebe-se como o jornal O Povo acabou tornando-se maior divulgador de projetos estatais ligados à cultura, por conta das articulações políticas advindas da longevidade de atuação na cena pública. Mesmo que a empresa demonstrasse interesse no cangaço antes disso, parece ser apenas nessa ocasião que se coloca como um empreendedor de sua memória, por tornálo um tema recorrente, uma bandeira editorial e uma questão pública. Atitude relacionada ao seu projeto editorial de modernização, que aproveitou para se apropriar de tema que foi tornando-se capital nos projetos da política cultural cearense. Mas, como vimos, enfrenta resistência de certas linhas editoriais do Diário do Nordeste que questiona, às vezes, essa abordagem cultural do tema ${ }^{19}$.

Em suma, os jornais O Povo e Diário do Nordeste vão se fazendo em relação ao cangaço, nos momentos destacados, a partir de demandas específicas, na busca de intervenção na agenda social, pela formação de opinião pública e por legitimidade frente ao assunto. Embora as peculiaridades se entrecruzem, é possível destacar ações que se sobressaem.

No primeiro momento aqui tratado, com o "boom da memória" cangaceira, advindo com a minissérie "Lampião e Maria Bonita”, no começo dos anos 1980, os jornalistas operam a valoração de memórias vivas, sobretudo de ex-cangaceiros, para tentar diferenciar o que acreditavam ser "verdade" e "mentira". No segundo momento, com o cinquentenário de morte de Lampião, em 1988, houve preocupação explícita dos jornalistas em refletir sobre apropriações de grupos que demarcavam o que deve ser lembrando e esquecido. No terceiro momento, com a reestruturação das linhas editoriais

\footnotetext{
19 Convém registrar que as divergências político-partidárias entre os jornais carecem de discussão na historiografia cearense.
} 
dos seus cadernos culturais e das mudanças nas políticas culturais engendradas pela Secult-CE, sobretudo, no meio dos anos 1990, há maior clivagem na abordagem, fazendo com que os jornalistas dividam a cena com intelectuais, especialistas e técnicos no assunto.

Particularmente, o jornal O Povo torna-se empreendedor da memória do cangaço, enquanto o Diário parece sinalizar mais críticas ao tema provavelmente devido à sua proximidade com cidades interioranas, que conservaram ressentimentos, mas também como efeito dos empreendimentos do concorrente. Importante enfatizar que a base editorial formada nesse último momento tem larga incidência contemporaneamente, nos periódicos, por servir como parâmetro para várias notícias ligadas ao tema.

\section{Considerações finais}

As ressignificações cearenses da memória do cangaço nas identidades nordestinas manifestam diferentes sentidos desse tema sensível marcado pelo dilema do lembrar ou esquecer. Nesse contexto, o fortalecimento da cultura mnemônica na cena pública do estado não aconteceu no cinquentenário de morte de Lampião, como no caso de outros estados nordestinos que tiveram suas ações mais demarcadas pelo imperativo do "dever de memória". A guinada teria acontecido no meio da década de 1990, com a reestruturação das políticas culturais da Secult-CE, que, em parceria com setores privados, apropriou-se intensamente de algumas produções culturais do cangaço em seus projetos de modernização através do setor audiovisual, as quais estavam consideravelmente envolvidas por usos que mais circulam um "desejo de tradição" em torno do tema.

Especificamente, os jornais O Povo e Diário do Nordeste, situados em lugares privilegiados de produção de memória, participaram desse processo de ressignificação. Por conta de projetos editoriais culturais, articulações políticas com a Secult-CE e tentativa de legitimar-se como autoridade no assunto, o jornal O Povo tornou o tema uma pauta recorrente e foi responsável por valorar suas memórias vivas, de filmes, de objetos, de obras artísticas etc. A gestação dessa ressignificação aconteceu paulatinamente, com 
a participação de muitos sujeitos ao longo do tempo. Pode-se dizer que a Secult-CE e o jornal O Povo formaram uma governança empreendedora da memória do cangaço. Um sujeito central na mediação foi o intelectual Daniel Lins que, possuindo vínculos profissionais com as duas instituições, corroborou com projetos de modernização via uso da cultura local, ao passo que provocou discussões a partir do lugar social privilegiado que ocupava, como algumas que levavam à cena diferentes partes 'mal-ditas' do cangaço, cujo dito lado feminino de Lampião era o mais polêmico.

A sinalização de que a memória do cangaço tem como uma de suas facetas o aspecto de patrimônio cultural nordestino reivindicado, dissonante e contestado faz sentido. A memória pode ser significativa para muitos nordestinos, mas isso não impede que, por um lado, não exista consenso quanto ao seu valor, e, por outro, que os questionamentos à pretensa herança continuem vingando. A maior singularidade cearense talvez seja notar como valorações que muito circularam em nível público sejam aquelas que transgridam visões cristalizadas da identidade nordestina, o que mostra como o campo do patrimônio é sitiado de contendas.

\section{Referências}

ALBUQUERQUE JR, Durval Muniz. A Invenção do Nordeste e outras artes. São Paulo: Cortez, 2011.

ALMEIDA, Fenelon. Lampião agora é mito: parte I - falar em cangaço também virou moda. O Povo, Fortaleza, 19 de julho 1982. Caderno 2, p. 1 b.

ANTUNES, Gibson. Guia de redação e estilo. Fortaleza: Demócrito Rocha, 2002.

ARAÚJO SÁ, Antônio F. O cangaço nas batalhas da memória. Recife: Ed. UFPE, 2011.

ARAÚJO SÁ, Antônio F.; RAMOS FILHO, Vagner Silva. Dossiê 80 anos da morte de Lampião: releituras do cangaço. Ponta de Lança, São Cristovão, v. 12, n. 22, 234 p. jan.-jun. 2018.

ASHWORTH, Gregory; GRAHAM, Brian; TUNBRIDGE, John. Pluralising pasts: heritage, identity and place in multicultural societies. London: Pluto Press, 2007. 
“Da praça pública ao palácio”: a atuação da imprensa cearense na cultura da memória do cangaço (19821995)

BARBALHO, Alexandre. A modernização da cultura: políticas para o audiovisual nos Governos Tasso Jereissati e Ciro Gomes (Ceará, 1987 - 1998). Fortaleza: Imprensa Universitária, 2005.

CARVALHO, Eleuda. Dossiê Lampião. O Povo, Fortaleza, 11 dez. 1993. Vida \& Arte.

CEARÁ. Arquivo Público do Estado do Ceará - Intermediário (AINT-CE). Fundo Secult, Investimento em regime de execução especial: prestação de contas. caixa 49, 1995.

CEARÁ. Arquivo Público do Estado do Ceará - Intermediário (AINT-CE). Fundo Secretaria de Cultura. Material de divulgação da Lei Jereissati. Caixa - Diversos, 1996.

CLEMENTE, Marcos Edilson de. Lampiões acesos: o cangaço na memória coletiva. Aracaju: Editora da UFS, 2009.

COZINHEIRA de Lampião. Diário do Nordeste, Fortaleza, 4 de fevereiro 1982. Caderno B, Variedade, p. 28.

FARIA CRUZ, Heloisa; CUNHA PEIXOTO, Maria do R. Na oficina do historiador: conversas sobre história e imprensa. Projeto História, São Paulo, n.35, p. 253-270, dez. 2007.

GALVÃO, Lucia. Elegância no Cangaço. O Povo, Fortaleza, 8 mai. 1995. Vida \& Arte, p. 1 b.

GONÇALVES, Janice. Pierre Nora e o tempo presente: entre a memória e o patrimônio cultural. Historiae, Rio Grande, v.3, n.3, p. 27-28, 2012.

GRUSPAN, Elise Jasmin. Lampião, senhor do sertão. São Paulo: Ed. da USP, 2006.

HALL, Stuart. A identidade cultural na pós-modernidade. Rio de Janeiro: DP\&A. 2011.

HARTOG, François. Regimes de historicidade: presentismo e experiência do tempo. Belo Horizonte: Autêntica Editora, 2013.

HARVEY, David. Do administrativismo ao empreendedorismo: a transformação da governança urbana no capitalismo tardio. In: HARVEY, David. A produção capitalista do espaço. São Paulo: Annablume, 2005, p. 163-191.

HEYMANN, Luciana; ARRUTI, José Mauricio. Memória e reconhecimento: notas sobre as disputas contemporâneas pela gestão da memória na França e Brasil. In: ROCHA, Helenice et. al (Org.). Qual o valor da história hoje? Rio de Janeiro: Editora da Fundação Getúlio Vargas, 2012, p. 135-160. 
“Da praça pública ao palácio”: a atuação da imprensa cearense na cultura da memória do cangaço (19821995)

HOBSBAWM, Eric. Bandidos. Rio de Janeiro: Forense-Universitária, 1975.

HUYSSEN, Andreas. Culturas do passado-presente: modernismos, artes visuais, políticas da memória. Rio de Janeiro: Contraponto: Museu de Arte do Rio, 2014.

JELIN, Elizabeth. Los trabajos de la memoria. Madrid: Siglo XXI de España Ed. S.A., 2002.

LIMA, Estácio de. O mundo estranho dos cangaceiros. Salvador: Ed. Itapoã, 1965.

LIVRO desmitifica lendas do cangaço. Diário do Nordeste, Fortaleza, 18 de junho $1995.1^{\circ}$ Caderno, Interior, p. 16.

MARCO na imprensa cearense. Diário do Nordeste, Fortaleza, 30 de dezembro 2006. Disponível em: http://diariodonordeste.verdesmares.com.br/marco-na-imprensacearense-1.345825. Acesso em: 29 de fev. de 2019.

MELLO, Frederico Pernambucano. Guerreiros do sol: violência e banditismo no Nordeste do Brasil. São Paulo: A Girafa Editora, 2004.

MENEGUELLO, Cristina. Patrimônios sombrios, memórias difíceis. In: FLORES, Maria Bernardete Ramos; PETERLE, Patrícia (Orgs.). História e arte: herança, memória e patrimônio. São Paulo: Rafael Copetti Editor, 2014, p. 46-66.

MENEZES, Sônia. A operação midiográfica; da escritura do evento na cena pública à inscrição do acontecimento no tempo - a mídia, a memória e a história. In: DELGADO, Lucilia de A. N.; FERREIRA, Marieta de M. (Org.). História do tempo presente. Rio de Janeiro: Editora FGV, 2014, p. 285-320.

NOGUEIRA, Antonio Gilberto Ramos. O campo do patrimônio cultural e a história: itinerários conceituais e práticas de preservação. Antíteses, Londrina, v.7, n.14, p. 45-67, 2014.

NOGUEIRA, Antonio Gilberto Ramos; RAMOS FILHO, Vagner Silva. Intelectuais, Patrimônio e o Centro de Referência Cultural do Ceará - CERES. In: SCHIAVON, Carmem G. Burgert; PELEGRINI, Sandra de Cássia A. (Org.). Patrimônios plurais: iniciativas e desafios. Rio Grande: Ed. da FURG, 2016, p. 273-285.

NORA, Pierre. L'ère de la commémoration. In: NORA, Pierre. Les lieux de mémorie. Paris: Gallimard, 1992. V. 3.

OLIVEIRA, Israel Carvalho de. Entre a cultura e o espírito: domínios da intelectualidade cearense na política cultural (1966-1980). Dissertação (Mestrado em História) Universidade Federal do Ceará, Fortaleza, 2014. 
PAULA, Ethel de. Cangaço: ética e estética. Diário do Nordeste, Fortaleza, 2 de maio 1995. Caderno 3, Variedades, p. 7.

PEREIRA, Mateus Henrique de Faria. A história do tempo presente: do futurismo ao presentismo? Humanidades, v. 58, Brasília, 2011, p. 56-65.

PERICÁS, Luiz B. Os cangaceiros: ensaio de interpretação histórica. São Paulo: Boitempo, 2010.

PERICÁS, Luiz B. O cangaço desmistificado. In: GAMA, Aldo. Brasil de Fato, São Paulo, 02 mai. 2011. Cultura. Disponível em: http://antigo.brasildefato.com.br/node/6182. Acesso em: 05 de jul. 2019.

PINHEIRO, Humberto. Lampião: a luz da revolta social. O Povo, Fortaleza, 28 jul. 1988. Caderno 2.

POULOT, Dominique. Uma história do patrimônio no Ocidente. São Paulo: Est. liberdade, 2009.

POLLAK, Michael. Memória, esquecimento e silêncio. Estudos Históricos, Rio de Janeiro, v. 2, n. 3, p. 3-15, 1989.

QUADRAT, Samantha Viz. É possível uma história pública dos temas sensíveis no Brasil? In: MAUAD, Ana Maria; SANTHIAGO, Ricardo; BORGES, Viviane Trindade (Org.). Que história pública queremos? São Paulo: Letra e Voz, 2018, p. 213-220.

QUEZADO, Rozanne. Conferência encerra jornada sobre Lampião. O Povo, Fortaleza, 12 ago. 1988. p. 20.

RAMOS FILHO, Vagner Silva. “Século Virgulino": o cangaço nas (con)fusões da memória entre comemorações de Lampião no tempo presente. Dissertação de Mestrado em História. Universidade Federal do Ceará (UFC), 2016.

RAMOS FILHO, Vagner Silva. (O)culto pelo patrimônio: (pre)tensões da memória do cangaço na cultura nordestina. In: CUNHA FILHO, F. Humberto; BOTELHO, Isaura; SEVERINO, J. Roberto (Orgs.). Direitos culturais. Salvador: EDUFBA, 2018a, p. 189-208. (Cultura e pensamento; 1 ).

RAMOS FILHO, Vagner Silva. O tombamento da Gruta de Angico: disputas da memória do cangaço no sertão nordestino. Clio, Recife, n.36.2, p. 260-284, jul.-dez. 2018b. 
RAMOS FILHO, Vagner Silva. Lampião 'mal-dito': o gênero em narrativas de um mito em disputa. In: GÓIS, Cecília dos Santos; LIMA, Marília Gabriela de. (Org.). Diversidade e resistência: coletânea literária LGBT. Fortaleza: Aliás - Selo Editorial, 2018c, v. 1, p. 147-162.

ROBIN, Régine. A memória saturada. Campinas: Ed. Unicamp, 2016.

ROUSSO, Henry. A memória não é mais o que era. In: FERREIRA, Marieta de Moraes; AMADO, Janaína (Orgs.). Usos e abusos da história oral. Rio de Janeiro, Editora da FGV, 1996.

ROUSSO, Henry. Sobre a história do tempo presente: entrevista com o historiador Henry Rousso. In: AREND, Silvia Maria Fávero; MACEDO, Fábio. Tempo e Argumento, Florianópolis v.1, n.1, 2009, p. 201-2016.

SILVA, Aguinaldo. Lampião e Maria Bonita. Minissérie da Rede Globo de Televisão, 1982.

VARELLA, Flávia Florentino (Org.) et al. Tempo presente \& usos do passado. Rio de Janeiro: Editora FGV, 2012.

VICELMO, Antonio. Pesquisador cearense relata a face cruel de Lampião. Diário do Nordeste, Fortaleza, 28 jul. 1988. Segundo Caderno, Variedades, p. 6.

WIESEBRON, Marianne L. Historiografia do cangaço e estado atual da pesquisa sobre o banditismo a nível nacional e internacional. Coleção Mossoroense (Fundação Vingt-un Rosado), Mossoró, n. 90, 1997. Série "A".

WINTER, Jay. A geração da memória: reflexões sobre o "boom da memória" nos estudos contemporâneos de história. In: SELIGMANN-SILVA, Márcio (Org.). Palavra e imagem: memória e escritura. Chapecó: Argos, 2006, p. 67-90. 